\title{
PERSEPSI ANTARA RISIKO KESELAMATAN BERKENDARAAN DENGAN PERILAKU PEMAKAIAN SAFETY BELT PADA DRIVER TRUK
}

\author{
Muhamad Bob Anthony \\ Program Studi Teknik Industri, Fakultas Teknik, Universitas Serang Raya \\ Email: tonipbmti@gmail.com
}

\begin{abstract}
Abstrak - Kematian dan cedera akibat kecelakaan lalu lintas telah menjadi masalah kesehatan masyarakat di seluruh dunia termasuk Indonesia. Data yang paling menyedihkan dari korban meninggal dunia akibat kecelakaan lalu lintas ditemukan bahwa 10.428 korban jiwa tahun 2017 karena pengemudi tidak menggunakan sabuk pengaman. Penelitian ini bertujuan melihat hubungan antara persepsi risiko keselamatan yaitu kemampuan, pengetahuan dan factor lingkungan dengan perilaku penggunaan sabuk keselamatan pada driver truck di perusahaan tambang. Penelitian ini merupakan penelitian kausal komparatif yaitu penelitian yang menyatakan hubungan satu variabel menyebabkan variabel lainnya. Yang dipengaruhi adalah variabel terikat (dependent) yaitu perilaku penggunaan safety belt dan variabel yang mempengaruhi adalah variabel bebas (independent) yaitu persepsi risiko keselamatan berkendaraan. Partisipan adalah 25 driver truk perusahaan tambang. Data yang didapat kemudian diolah dan dianalisa menggunakan program SPSS versi 16. Berdasarkan hasil pengolahan data dan analisa tersebut didapat bahwa kemampuan, pengetahuan dan faktor lingkungan kerja mempunyai pengaruh terhadap perilaku pemakaian safety belt.
\end{abstract}

Kata kunci: Keselamatan; Perilaku; Persepi Risiko; Sabuk Keselamatan

\begin{abstract}
Deaths and injuries from traffic accidents have become health problems for people throughout the world including Indonesia. The saddest data from the victims who died due to traffic accidents found that 10,428 people were killed in 2017 because the drivers did not use seat belts. This research aims to see the relationship between the perception of safety risk i.e. the ability, knowledge and environmental factors with the behavior of the use of safety belts in truck drivers in mining companies. This research is a comparative causal research i.e. research that states the relationship of one variable causes other variables. What is affected is the dependent variable, namely the use of safety belt behavior and the influencing variable is the independent variable, namely the perception of the risk of driving safety. Participants are 25 mining company truck drivers. The data obtained is then processed and analyzed using the SPSS version 16. Based on the results of data processing and analysis, it is found that the ability, knowledge and work environment factors have an influence on the safety belt usage behavior.
\end{abstract}

Keywords: Behavior; Risk Perception; Safety; Safety Belt

\section{PENDAHULUAN}

Kematian dan cedera akibat kecelakaan lalu lintas telah menjadi masalah kesehatan masyarakat yang penting di seluruh dunia termasuk Indonesia. Sejak kendaraan bermotor ditemukan lebih dari seabad yang lalu, diperkirakan sekitar 30 juta orang telah terbunuh akibat kecelakaan lalu lintas (Garcia, 2007).

Badan Keselamatan Jalan Raya Amerika Serikat (NHTSA) telah merilis data jumlah kematian dalam kecelakaan lalu lintas, yang meningkat sebanyak 5,6 persen menjadi 37.461 korban jiwa (2017). Data paling menyedihkan dari korban meninggal dunia akibat kecelakaan lalu lintas, bahwa 10.428 korban jiwa tahun lalu karena pengemudi tidak menggunakan sabuk pengaman. Padahal, menggunakan sabuk pengaman merupakan pekerjaan yang ringan dan sangat efektif mengurangi kecelakaan (Aszhari, 2017).

Persepsi adalah proses yang digunakan individu mengelola dan menafsirkan kesan indera mereka dalam rangka memberikan makna kepada lingkungan mereka. Meski demikian apa yang dipersepsikan seseorang dapat berbeda dari kenyataan yang obyektif (Robbins, 2006). Terdapat dua metode pengukuran sikap terdiri dari metode self report dan pengukuran involuntary behavior. Self report merupakan suatu metode dimana jawaban yang diberikan 
dapat menjadi indikator sikap seseorang. Namun kelemahannya adalah bila individu tidak menjawab pertanyaan yang diajukan maka tidak dapat mengetahui pendapat atau sikapnya. Sedangkan, involuntary behaviour dilakukan jika memang diinginkan atau dapat dilakukan oleh responden, dalam banyak situasi akurasi pengukuran sikap dipengaruhi kerelaan responden (Azzahy, 2010).

Persepsi resiko (risk perception) didefinisikan sebagai pikiran, kepercayaan, dan konstruk seseorang akan kejadian-kejadian negatif yang mungkin terjadi pada suatu kejadian (Oltedal, 2004). Persepsi resiko dipengaruhi oleh pengetahuan, personal, konteks, kualitas lingkungan kerja, kepuasan dengan ukuran safety, sikap terhadap resiko dan safety, dan budaya safety (Faradina, 2007).

Menurut Kathryn Mearns, persepsi resiko dipengaruhi oleh beberapa faktor, yaitu pengetahuan, personal, konteks, kualitas lingkungan kerja, kepuasan dengan ukuran safety, sikap terhadap resiko dan budaya safety (Faradina, 2007).

Perilaku adalah tindakan atau aktivitas dari manusia itu sendiri yang mempunyai bentangan yang sangat luas antara lain berjalan, berbicara, menangis, tertawa, bekerja, kuliah, menulis, membaca, dan sebagainya. Dari uraian ini dapat disimpulkan bahwa yang dimaksud perilaku manusia adalah semua kegiatan atau aktivitas manusia, baik yang diamati langsung, maupun yang tidak dapat diamati oleh pihak luar (Notoatmodjo, 2010).

Definisi sabuk keselamatan menurut keputusan menteri perhubungan nomor : KM 37 tahun 2002 adalah perangkat peralatan yang merupakan bagian dan terpasang pada kendaraan bermotor, yang berfungsi untuk mencegah benturan terutama bagian kepala dan dada dengan bagian kendaraan sebagai akibat perubahan gerak kendaraan secara tiba-tiba. Komponen safety belt berdasarkan surat keputusan menteri perhubungan nomor KM. 37 tahun 2002 tentang persyaratan teknis sabuk keselamatan dalam pasal 3 disebutkan, bahwa komponen sabuk keselamatan terdiri dari pita sabuk (webbing), pengunci sabuk (buckle), pengatur panjang (length adjuster/retractor), penuntun gelincir (slip guide), pengikat (fitting), jangkar (anchorage).

Tujuan penelitian ini adalah untuk mengetahui persepsi antara resiko keselamatan berkendaraan yaitu kemampuan, pengalaman dan lingkungan kerja dengan perilaku pemakaian safety belt pada driver truk perusahaan tambang.

Hipotesis dalam penelitian ini adalah :

Ho : Persepsi risiko keselamatan berkendaraan yaitu kemampuan, pengalaman dan lingkungan kerja memiliki hubungan yang positif terhadap penggunaan safety belt pada driver truk.

H1 : Persepsi risiko keselamatan berkendaraan yaitu kemampuan, pengalaman dan lingkungan kerja tidak memiliki hubungan yang positif terhadap penggunaan safety belt pada driver truk.

\section{METODE PENELITIAN}

Objek dalam penelitian ini difokuskan hanya pada persepsi risiko keselamatan berkendaraan yaitu kemampuan, pengalaman dan faktor lingkungan kerja dengan perilaku penggunaan safety belt pada driver truk.

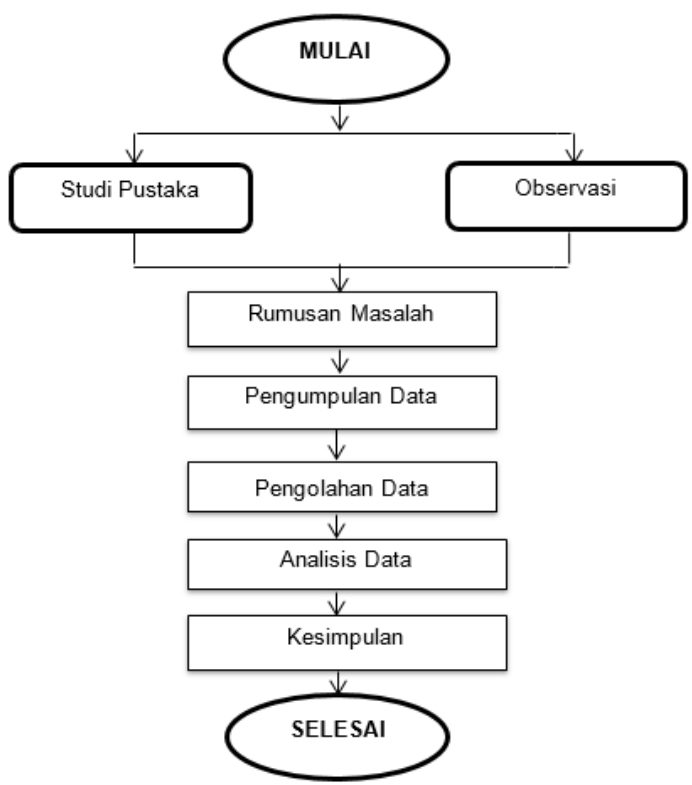

Gambar 1. Metodologi penelitian

Penelitian ini merupakan penelitian kausal komparatif yaitu penelitian yang menyatakan hubungan satu variabel menyebabkan variabel lainnya. Yang dipengaruhi adalah variabel terikat (dependent) yaitu perilaku penggunaan safety belt dan variabel yang mempengaruhi adalah variabel bebas (independent) yaitu persepsi risiko keselamatan berkendaraan.

Objek penelitian ini adalah driver truk perusahaan tambang dengan waktu penelitian dilaksanakan mulai bulan Juni hingga September 2018. Sumber data yang digunakan dalam penelitian ini berasal dari data primer dan data sekunder. Sumber data secara keseluruhan diperoleh dari tempat penelitian.

Pengolahan dan analisa data menggunakan program SPSS Versi 16 dengan melakukan Uji Validitas, Uji Reliabilitas dan Uji Regresi. 
SPSS adalah suatu program yang berfungsi untuk menganalisis data, melakukan perhitungan statistik baik untuk statistik parametrik maupun yang bukan parametrik dengan berbasis window (Ghozali, 2006). Uji validitas dan reliabilitas dilakukan untuk memastikan alat ukur tersebut merupakan alat ukur yang akurat dan dapat dipercaya. Validitas menunjukkan sejauh mana suatu alat pengukur itu mengukur apa saja yang ingin diukur. Sedangkan reliabilitas menunjukkan sejauh mana suatu hasil pengukuran relatif konsisten apabila pengukuran terhadap aspek yang sama pada alat ukur yang sama (Ghozali, 2006). Validitas pengukuran dapat dilihat pada nilai total korelasi pearson antara data-data yang yang dikoreksi tampilan SPSS uji reliabilitas. Secara umum, jika nilai nilai total korelasi pearson antara data-data yang yang dikoreksi > 0.2 dan Probabilitasnya dibawah 0.01 (signifikan) maka dapat dikatakan valid (Ghozali, 2006). Reliabilitas diukur dengan menggunakan uji statistik Nilai Cronbach Alpha. Jika nilai Cronbach Alpha > 0.6 maka hal ini menunjukkan bahwa pengukuran yang digunakan handal (Ghozali, 2006).

Analisa regresi pada dasarnya adalah studi mengenai ketergantungan variabel terikat dengan satu atau lebih variabel variabel penjelas atau bebas, dengan tujuan untuk memperkirakan dan atau memprediksi rata-rata populasi atau nilai rata-rata variabel terikat berdasarkan nilai variabel bebas yang diketahui. Regresi sederhana untuk menguji pengaruh satu variabel bebas (metrik) terhadap satu variabel terikat (metrik). Dalam analisa regresi, selain mengukur kekuatan hubungan antara dua variabel, juga menunjukkan arah hubungan antara variabel terikat dengan variabel bebas. Secara statistik, ketepatan fungsi regresi sampel dalam menaksir nilai aktual ini setidaknya dapat diukur dari nilai koefisien determinasi $\left(R^{2}\right)$, nilai statistik $F$ dan nilai statistik t (Ghozali, 2006).

\section{Koefisien Determinasi $\left(\mathbf{R}^{2}\right)$}

Koefisien determinasi $\left(R^{2}\right)$ pada intinya mengukur seberapa jauh kemampuan model dalam menerangkan variasi-variabel terikat. Nilai koefisien determinasi adalah antara nol dan satu. Nilai $R^{2}$ yang kecil berarti kemampuan variabelvariabel bebas dalam menjelaskan variasivariabel terikat amat terbatas. Nilai yang mendekati satu berarti variabel-variabel bebas memberikan hampir semua informasi yang dibutuhkan untuk memprediksi variasi-variabel terikat (Ghozali, 2006).

\section{Uji Signifikan simultan (Uji Statistik F)}

Uji statistik $F$ pada dasarnya menunjukkan apakah semua variabel bebas yang dimasukkan dalam model mempunyai pengaruh secara bersama-sama terhadap variabel terikat. Bila Nilai $F$ mempunyai probabilitas < 0.05 dan signifikan maka semua variabel bebas secara serentak dan signifikan mempengaruhi variabel (Ghozali, 2006).

\section{Uji Signifikan Parameter (Uji Statistik t)}

Uji statistik t pada dasarnya menunjukkan seberapa jauh pengaruh satu variabel penjelas atau bebas secara tepat dalam menerangkan variasi variabel terikat. Jika Nilai t mempunyai probabilitas < 0.05 dan signifikan maka suatu variabel bebas secara tepat mempengaruhi variabel terikat (Ghozali, 2006).

\section{HASIL DAN PEMBAHASAN}

Populasi dalam penilitian ini adalah driver sebanyak 25 orang. Populasi adalah wilayah generalisasi yang terdiri atas obyek/subyek yang mempunyai kualitas dan karakteristik tertentu yang ditetapkan oleh peneliti untuk dipelajari dan kemudian ditarik kesimpulannya. Jadi populasi bukan hanya orang, tetapi juga obyek dan benda-benda alam yang lain. Populasi juga bukan sekedar jumlah yang ada pada obyek/subyek yang dipelajari, tetapi meliputi seluruh karakteristik/sifat yang dimiliki oleh subyek atau obyek yang diteliti itu (Sugiyono, 2014).

Sampel yang digunakan dalam penelitian ini adalah sampel jenuh, mengingat jumlah populasi relatif sedikit sehingga jumlah sampel sama dengan jumlah populasi yaitu sebanyak 25 orang. Sebagaimana hal tersebut dikemukan oleh Sugiyono (2014) bahwa sampel jenuh adalah teknik penentuan sampel bila semua anggota populasi digunakan sebagai sampel.

Menurut Sugiyono (2014) sampel adalah bagian dari jumlah data dan karakteristik yang dimiliki oleh populasi.

\section{Uji Validitas}

Berdasarkan data hasil uji validitas pada Tabel 1, dapat dijelaskan bahwa dari 25 item data kemampuan, pengetahuan, faktor lingkungan kerja dan penggunaan safety belt dinyatakan valid pada total korelasi pearson antara masing-masing data yang dikoreksi yaitu adalah lebih besar dari 0.2 dan signifikan (probabilitasnya dibawah 0.01). 
Tabel 1. Uji Validitas

\begin{tabular}{|c|c|c|c|c|c|}
\hline \multicolumn{6}{|c|}{ Correlations } \\
\hline & & Kemampuan & Pengetahuan & \begin{tabular}{c|} 
Eaktor \\
Lingkungan
\end{tabular} & $\begin{array}{l}\text { Penggunaaan } \\
\text { Safety Belt }\end{array}$ \\
\hline \multirow[t]{3}{*}{ Kemampuan } & $\begin{array}{l}\text { Pearson } \\
\text { Correlation }\end{array}$ & 1 & .305 & $.568^{*}$ & $.650^{\circ}$ \\
\hline & $\begin{array}{l}\text { Sig. (2- } \\
\text { tailed) }\end{array}$ & & .138 & .003 & .000 \\
\hline & $\mathrm{N}$ & 25 & 25 & 25 & 25 \\
\hline \multirow[t]{3}{*}{ Pengetahuan } & $\begin{array}{l}\text { Pearson } \\
\text { Correlation }\end{array}$ & .305 & 1 & .386 & $.709^{\prime \prime}$ \\
\hline & $\begin{array}{l}\text { Sig. (2- } \\
\text { tailed) }\end{array}$ & .138 & & .057 & .000 \\
\hline & $\mathrm{N}$ & 25 & 25 & 25 & 25 \\
\hline \multirow[t]{3}{*}{ Fakter Lingkungan } & $\begin{array}{l}\text { Pearson } \\
\text { Correlation }\end{array}$ & $.568^{\circ}$ & .386 & 1 & $.612^{* \prime}$ \\
\hline & $\begin{array}{l}\text { Sig. (2- } \\
\text { tailed) }\end{array}$ & .003 & .057 & & .001 \\
\hline & $\mathrm{N}$ & 25 & 25 & 25 & 25 \\
\hline \multirow[t]{3}{*}{ Penggunaan Safety Belt } & $\begin{array}{l}\text { Pearson } \\
\text { Correlation }\end{array}$ & $650^{\prime \prime}$ & $.709^{\prime \prime}$ & $.612^{*}$ & \\
\hline & $\begin{array}{l}\text { Sig. (2- } \\
\text { tailed) }\end{array}$ & .000 & .000 & .001 & \\
\hline & $\mathrm{N}$ & 25 & 25 & 25 & 25 \\
\hline
\end{tabular}

**. Correlation is significant at the 0.01 level (2-tailed).

\section{Uji Reliabilitas}

Berdasarkan data hasil uji reliabilitas pada Tabel 2 bahwa nillai Cronbach Alpha adalah 0.824 atau bisa dinyatakan > 0.6 untuk semua variabel. Hal ini menunjukkan bahwa semua indikator-indikator kemampuan, pengetahuan, factor lingkungan kerja dan penggunaan safety belt yang digunakan memiliki reliabilitias yang baik.

Tabel 2. Uji Reliabilitas

Reliability Statistics

\begin{tabular}{|r|r|}
\hline $\begin{array}{c}\text { Cronbach's } \\
\text { Alpha }\end{array}$ & N of Items \\
\hline .824 & 4 \\
\hline
\end{tabular}

\section{Analisa Regresi (Koefisien Determinasi $\mathbf{R}^{2}$ )}

Tabel 3. Uji determinasi semua variabel terhadap penggunaan safety belt

Model Summary

\begin{tabular}{|l|r|r|r|r|}
\multicolumn{1}{|c|}{ Model Summary } \\
\hline Model & \multicolumn{1}{c|}{$\mathrm{R}$} & R Square & $\begin{array}{c}\text { Adjusted R } \\
\text { Square }\end{array}$ & $\begin{array}{c}\text { Std. Error of } \\
\text { the Estimate }\end{array}$ \\
\hline 1 & $.857^{\mathrm{a}}$ & .735 & .697 & 1.09316 \\
\hline
\end{tabular}

a. Predictors: (Constant), Faktor Lingkungan, Pengetahuan, Kemampuan

Dari tabel 3 di atas diketahui bahwa nilai $\mathrm{R}^{2}$ sebesar 0,735 . Hal ini menunjukkan, bahwa variabel kemampuan, pengetahuan dan lingkungan secara simultan mampu memberikan kontribusi pengaruh terhadap penggunaan safety belt sebesar 73,5\%, sedangkan sisanya dipengaruhi oleh faktor lain yang tidak diteliti.
Tabel 4. Uji determasi kemampuan terhadap penggunaan safety belt

\begin{tabular}{|l|c|r|r|r|}
\multicolumn{5}{|c|}{ Model Summary } \\
\hline Model & \multicolumn{1}{|c|}{$\mathrm{R}$} & $\mathrm{R}$ Square & $\begin{array}{c}\text { Adjusted R } \\
\text { Square }\end{array}$ & $\begin{array}{c}\text { Std. Error of } \\
\text { the Estimate }\end{array}$ \\
\hline 1 & $.650^{\mathrm{a}}$ & .423 & .398 & 1.54060 \\
\hline
\end{tabular}

a. Predictors: (Constant), Kemampuan

Dari tabel 4 analisis regresi di atas, kemampuan terhadap penggunaan safety belt menunjukkan Nilai $R^{2}$ terkoreksi 0.423 sehingga dapat dinyatakan variasi penggunaan safety belt dapat dijelaskan oleh variasi dari variabel bebas yaitu kemampuan.

Tabel 5. Uji determasi pengetahuan terhadap penggunaan safety belt Model Summary

\begin{tabular}{|l|r|r|r|r|}
\hline Model & R & R Square & \multicolumn{1}{c|}{$\begin{array}{c}\text { Adjusted R } \\
\text { Square }\end{array}$} & $\begin{array}{r}\text { Std. Error of } \\
\text { the Estimate }\end{array}$ \\
\hline 1 & $.709 \mathrm{a}$ & .503 & .481 & 1.42965 \\
\hline
\end{tabular}

a. Predictors: (Constant), Pengetahuan

Dari tabel 5 analisis regresi di atas, pengetahuan terhadap penggunaan safety belt menunjukkan Nilai $\mathrm{R}^{2}$ terkoreksi 0.503 sehingga dapat dinyatakan variasi penggunaan safety belt dapat dijelaskan oleh variasi dari variabel bebas yaitu pengetahuan.

Tabel 6. Uji determasi faktor lingkungan kerja terhadap penggunaan safety belt

\begin{tabular}{|l|r|r|r|r|}
\hline & & & \multicolumn{1}{|c|}{ Adjusted R } \\
Model & R & R Square & $\begin{array}{c}\text { Std. Error of } \\
\text { the Estimate }\end{array}$ \\
\hline 1 & $.612^{\mathrm{a}}$ & .375 & .348 & 1.60307 \\
\hline
\end{tabular}

a. Predictors: (Constant), Faktor Lingkungan

Dari tabel 6 analisis regresi di atas, factor lingkungan kerja terhadap penggunaan safety belt menunjukkan Nilai $R^{2}$ terkoreksi 0.375 sehingga dapat dinyatakan variasi penggunaan safety belt dapat dijelaskan oleh variasi dari variabel bebas yaitu faktor lingkungan kerja.

\section{Uji Signifikan simultan (Uji Statistik F)}

Uji signifikansi simultan (uji statistik F) data kemampuan, pengetahuan dan lingkungan, didapat nilai $F$ sebesar 19.376 dengan probabilitas adalah 0 (nol) sehingga dapat dikatakan bahwa kemampuan, pengetahuan dan lingkungan berpengaruh terhadap penggunaan safety belt 


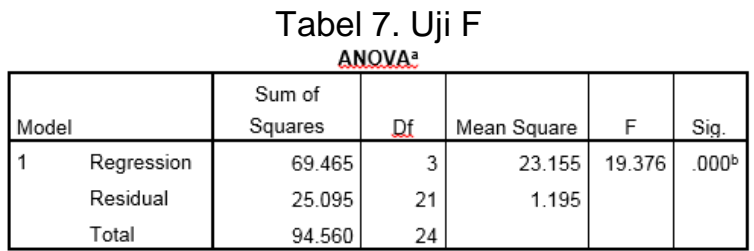

a. Dependent Variable: Renggunaan Safety Belt

b. Predictors: (Constant), Faktor Lingkungan, Pengetahuan. Kemampuan

\section{Uji Signifikan Parameter (Uji Statistik t)}

Uji signifikansi parameter (uji statistik t) pada tabel data 8 diatas kemampuan terhadap penggunaan safety belt signifikan pada 0 (nol) sehingga dapat disimpulkan bahwa variabel penggunaan safety belt dipengaruhi oleh kemampuan.

Tabel 8. Uji t kemampuan terhadap penggunaan safety belt

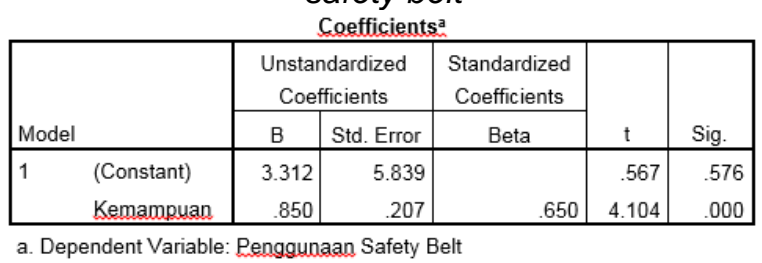

Uji signifikansi parameter (uji statistik t) pada tabel data 9 pengetahuan terhadap penggunaan safety belt signifikan pada 0 (nol) sehingga dapat disimpulkan bahwa variabel penggunaan safety belt dipengaruhi oleh pengetahuan

Tabel 9. Uji t pengetahuan terhadap penggunaan safety belt

\begin{tabular}{|c|c|c|c|c|c|c|}
\hline \multirow{2}{*}{\multicolumn{2}{|c|}{ Model }} & \multicolumn{2}{|c|}{$\begin{array}{c}\text { Unstandardized } \\
\text { Coefficients }\end{array}$} & \multirow{2}{*}{\begin{tabular}{|c|}
$\begin{array}{c}\text { Standardized } \\
\text { Coefficients }\end{array}$ \\
Beta \\
\end{tabular}} & \multirow[b]{2}{*}{$t$} & \multirow[b]{2}{*}{ Sig. } \\
\hline & & $\mathrm{B}$ & Std. Error & & & \\
\hline \multirow[t]{2}{*}{1} & (Constant) & 6.324 & 4.346 & & 1.455 & .159 \\
\hline & Pengetabuan & .752 & .156 & .709 & 4.823 & .000 \\
\hline
\end{tabular}

a. Dependent Variable: Renggunaan Safety Belt

Uji signifikansi parameter (uji statistik t) pada tabel data 10 pengetahuan terhadap penggunaan safety belt si gnifikan pada 0.001 atau dinyatakan < 0.05 sehingga dapat disimpulkan bahwa variabel penggunaan safety belt dipengaruhi oleh faktor lingkungan.

Tabel 10. Uji t faktor lingkunganterhadap penggunaan safety belt

\begin{tabular}{|c|c|c|c|c|c|c|}
\hline \multirow[b]{2}{*}{ Mode } & & \multicolumn{2}{|c|}{$\begin{array}{c}\text { Unstandardized } \\
\text { Coefficients }\end{array}$} & \multirow{2}{*}{$\begin{array}{c}\text { Standardized } \\
\text { Coefficients } \\
\text { Beta }\end{array}$} & \multirow[b]{2}{*}{ t } & \multirow[b]{2}{*}{ Sig. } \\
\hline & & B & Std. Error & & & \\
\hline \multirow[t]{2}{*}{1} & (Constant) & 9.630 & 4.752 & & 2.027 & .054 \\
\hline & $\begin{array}{l}\text { Faktor } \\
\text { Lingkungan }\end{array}$ & .650 & .175 & 612 & 3.714 & .001 \\
\hline
\end{tabular}

a. Dependent Variable: Penggunaan Safety Belt

\section{KESIMPULAN}

Berdasarkan teori-teori yang melandasi rumusan permasalahan yang ada dalam penelitian ini serta hasil pengamatan, dokumentasi dan hasil keluaran dari program statistik SPSS yang sudah dihimpun dan diolah, dapat diambil kesimpulan bahwa semua indikator-indikator yang digunakan dalam penelitian ini memiliki keakuratan, keabsahan (validitas) dan kehandalan (reliabilitas) yang baik. Dari tabel di atas diketahui bahwa nilai $R^{2}$ sebesar 0,735. Hal ini menunjukkan, bahwa variabel kemampuan, pengetahuan dan faktor lingkungan kerja secara simultan mampu memberikan kontribusi pengaruh terhadap penggunaan safety belt sebesar 73,5\%, sedangkan sisanya dipengaruhi oleh faktor lain yang tidak diteliti. Semua variabel kemampuan secara bersama-sama dan signifikan mempengaruhi penggunaan safety belt dimana nilai koefisien determinasi $R^{2}$ terkoreksi 0.423 dan nilai uji statistik $F \quad 19.376$ dengan probabilitas 0 (nol). Semua variabel pengetahuan secara bersama-sama dan signifikan mempengaruhi penggunaan safety belt dimana nilai koefisien determinasi Nilai $R^{2}$ terkoreksi 0.503 dan nilai uji statistik $F 19.376$ dengan probabilitas 0 (nol). Semua variabel faktor lingkungan kerja secara bersama-sama dan signifikan mempengaruhi penggunaan safety belt dimana nilai koefisien determinasi Nilai $R^{2}$ terkoreksi 0.375 dan nilai uji statistik $F 19.376$ dengan probabilitas 0 (nol). Hal ini memberi kesimpulan bahwa kemampuan, pengetahuan dan faktor lingkungan kerja mempunyai pengaruh terhadap perilaku pemakaian safety belt.

\section{DAFTAR PUSTAKA}

Aszhari, A. (Liputan6.com), Tanpa Sabuk Pengaman, Kematian Pengemudi Meningkat Tajam?, 9 Oktober 2017.

Azzahy, SG. 2010. Tentang persepsi.

Faradina, Triska. (2007). Gambaran Persepsi Supir Bajaj Daerah Pangkalan Blok M Terhadap Keselamatan Berkendara di Jalan Raya tahun 2007. Skripsi. Fakultas Kesehatan Masyarakat Universitas Indonesia

Fardaniah, R., Ini Alasan Orang Tidak Pakai Sabuk Pengaman, 28 Agustus 2016.

Gaikindo, Keselamatan Transportasi Publik akan Dinilai, 8 September 2016.

García-ferrer, A., De Juan, A., \& Poncela, P. (2007). The relationship between road traffic accidents and real economic activity in Spain: common cycles and health issues. Health Economics, 16(6), 603-626. 
Geller ES. (2001). The psycology of safety handbook. USA: Lewis Publishers.

Ghozali, I. Aplikasi SPSS. Cetakan IV. Badan Penerbit. Universitas Diponegoro: Semarang. 2016.

Handayani. et.al. (2016). "Persepsi Risiko Keselamatan Terhadap Perilaku Keselamatan Berkendara Pada Pengguna Kendaraan Roda Dua". Forum Ilmiah Volume 13 Nomor 1.

Notoatmodjo, S. (2003). Pendidikan dan Perilaku Kesehatan. Jakarta : Rineke Cipta.

Peraturan Menteri Tenaga Kerja dan Transmigrasi Republik Indonesia Nomor PER.08/MEN/VII/2010 Tentang Alat Pelindung Diri.

Robbins, S. 2006. Perilaku organisasi. PT Indeks: Kelompok Gramedia.

Sugiyono. 2014. Metode Penelitian Kuantitatif, Kualitatif, dan $R$ \& $D$. Bandung: Penerbit Alfabeta.

Surat Keputusan Menteri Perhubungan Nomor KM. 37 tahun 2002 tentang Persyaratan Teknis Sabuk Keselamatan. 